\title{
Expected Life Expectancy of Life Expectants Due to Covid-19 Phenotypes Reduced to Life Expectancy Cohorts
}

Shane Smyth*

Department of Neurology, Mater Misericordiae University Hospital, Dublin, Ireland

*Corresponding author: Shane Smyth, Department of Neurology, Mater Misericordiae University Hospital, Dublin, Ireland

\section{Opinion}

I met a man once who had Covid and he said that he felt it was bad for his health. He had a cough and I said o you poor man, you should go to hospital but he didn't go to hospital and when I called over to his house two days later to return his Sleepless in Seattle VHS tape, he was dead. I said what are you doing you should have gone to hospital but he did not go to hospital because he was dead and I think he was dead because of the Covid. In his house I found a note that said I have covid and I think I need to go to hospital but I like this scene with Hanks and I should finish it. He also had cooked pasta and beef and I did not eat it but his dog looked hungry and I gave it to his dog but the dog was dead. I don't know if the dog had covid but I think it's possible. I then called over to the neighbours and they were alive. I told them that the man and his dog were dead and they asked where was the Seattle tape and I said I thought I might take it home to watch Hanks and they said okay. I said there was some beef and pasta and they said they had sealeeak disease and could not eat it I suppose that's right. I decided I would give them the Hanks tape and they said even better come inside and we shall watch it. They made tea but when we sat down in the living room, they had a DVD player I see and the VHS did not play. They said what is this 1996 a VHS!? 2021 but they still were laughing that's okay, I guess. Then I had a dream and what happened was the same. I tell you what the dream was. It happened when I fell asleep on the couch. They had put something in my tea. It was milk. I met a man once who had Covid and he said that he felt it was bad for his health. He had a cough and I said o you poor man, you should go to hospital but he didn't go to hospital and when I called over to his house two days later to return his Sleepless in Seattle VHS tape, he was dead. I said what are you doing you should have gone to hospital but he did not go to hospital because he was dead and I think he was dead because of the Covid. In his house I found a note that said I have covid and I think I need to go to hospital but I like this scene with Hanks and I should finish it. He also had cooked pasta and beef and I did not eat it but his dog looked hungry and I gave it to his dog but the dog was dead. I don't know if the dog had covid but I think it's possible. I then called over to the neighbours and they were alive. I told them that the man and his dog were dead and they asked where was the Seattle tape and I said I thought I might take it home to watch Hanks and they said okay. I said there was some beef and pasta and they said they had seabeach disease and could not eat it I suppose that's right. I decided I would give them the Hanks tape and they said even better come inside and we shall watch it. They made tea but when we sat down in the living room, they had a DVD player I see and the VHS did not play. They said what is this 1996 a VHS!? 2021 but they still were laughing that's okay, I guess. 
*Corresponding author: Shane Smyth, Email: ssmyth@mater.ie

Next Submission with BGSR follows:

- $\quad$ Rapid Peer Review

- Reprints for Original Copy

- E-Prints Availability

- Below URL for auxiliary Submission Link: https://biogenericpublishers.com/submit-manuscript/ 